\title{
Work, Unity, and Aesthetic Plenitude in La Peste by Albert Camus
}

\author{
Carmen Romero Sánchez-Palencia
}

ma.romero@ufv.es

Faculty of Humanities, Universidad Francisco de Vitoria, Madrid, SPAIN

This work is part of the International Research Project: "Anthropology, hermeneutics and living work", Laborem-IRCOM, Francia.

Abstract

Article information

Albert Camus, and his work, is the perfect example of achievement through Received: personal growth, with a unitary conception of the individual and their relationship 29 March 2020 with the world and with others. In confronting the immediate, the author offers repose; in the face of the absurd, revolt, and in the face of a meaninglessness he proposes love. His task is advance, our advance, climbing a long ladder that we may also descend, although transformed, no longer as we were the first time. This project will analyse the book La Peste / The Plague, relating it and the ideas here expressed with the concept of work. Work being understood as something beyond mere occupation, or way of making a living, but the endeavours of the subject as an essential component of life. This becomes evident when one seeks to grow fully, in harmony with humanity as embodied by Camus' characters in a situation of collective emergency, in a city in the grip of the plague. The result is a hymn of hope, of momentary triumph not without repeated stumbles, recalling again and again what we are and what we can become. Just as in our own lives, the nebulous is the constant companion of victory, which is never entirely complete.

Keywords: Albert Camus; La Peste; Work; Unity; Humanity

DOI: 10.24071/joll.v20i2.2502

Available at https://e-journal.usd.ac.id/index.php/JOLL/index

This work is licensed under a Creative Commons Attribute-ShareAlike 4.0 International License

\section{Introduction: Life and Work}

The French philosopher, novelist, essayist, journalist, and playwright Albert Camus was born on November 7th, 1913 in Mondovi, in the then French colony of Algeria. His father was a descendant of the earliest French settlers in Algeria who came to seek their fortune. But before Camus was one year old, his father had enlisted in the Zouaves, serving in the French army during the First World War where he would die in battle from a head wound. Albert, then eight months old, came to know his father through the memories of his mother and a few discoloured, sepia photographs. The inheritance he left was limited to a few entries in the civil registry, some shell fragments, a War Cross, and a posthumous Military Medal (Todd, 1997, p. 27). From then on, war and desolation would accompany the author, as with so many artists of his generation, throughout his life and his work, and especially forging his insight into human suffering and his interest for the least fortunate.

The family soon moved but without leaving the working-class where they had 
lived. There they lived on the edge of poverty but not in misery: "The family moved from number 17 to number 92 of the Rue de Lyon, in the heart of Belcourt, the working-class neighbourhood in the east of Algiers, on the borders of Marabout, the Arab quarter" (Todd, 1999, p. 29). The modest home in which they lived had no running water nor electricity and was rented in the name of his maternal grandmother who would then assume the role of paternal authority and loquacity. This in contrast to his timid, illiterate, and silent mother, Catherine Hélène, who earned a living cleaning houses and suffered from a hearing ailment due to a childhood illness. Nevertheless, her son would always keep her close, inspiring some of this work. His mother never remarried and, while born in Algiers, had Spanish roots, something which would lead Camus to consider Spain as his second homeland. He and his older brother Lucien had an unfettered and syncretic childhood among simple Spanish, Arab, Italian, and French working people who taught them to true meaning of life. The preferred distraction was the cinema, where films were shown in episodes and young Albert would read the words on the screen out loud for his mother and grandmother, who often forgot her glasses.

Given their precarious economic situation, and thanks to the efforts of his teacher Louis Germain, Albert received a scholarship to continue his studies, first at the institute and then at the Faculty of Philosophy at the University of Algiers. In fact, Camus never forgot the help, dedication and efforts of Louis Germain and years later, in 1957, at the peak of his career, he would dedicate his Nobel Prize for Literature to his teacher. The teacher would also inspire the thought and personality of Doctor Bernard Rieux, the main character of the work analysed, La Peste.

As a young man he was diagnosed with pulmonary tuberculosis and he was hospitalised for a time. Although there was then no cure for his illness then, the doctors believed the best medicine was overeating and to avoid both football and the sun, two of Camus' beloved pastimes. And so he moved to the house of his uncle, the butcher Gustave Acault, where he avidly devoured the books in his library as there was not a single book in his mother's house.

The illness was the beginning of his lifelong individuality and sensitivity, requiring him to retire from time to time throughout his life to rest and restore his health. Thus, accustomed to living in the shadow of death, these moments of exile allowed the author to compose his own worlds, weaving together personal stories, truth, beauty, and compassion. In the world of art, everything can be explored, more fully developed, to allow understanding but never judgement. The tuberculosis would help steer his professional career towards literature. At the same time he graduated in Philosophy with a thesis about Plotinus and Saint Augustine relating classical Greek thought and Christianity. The university administration refused, in accordance with the law, to allow him to sit the civil service exam due to his poor health. Camus decided to dedicate himself to writing, a career he would combine with other work in journalism and publishing. Thus, his art became an ordered system, bringing together emotion, truth, beauty and community. In the words of the author:

For myself, I cannot live without my art. But I have never placed it above everything. If, on the other hand, it is because it cannot be separated from my fellow men, and it allows me to live, such as I am, on one level with them. It is a means of stirring the greatest number of people by offering a privileged picture of common joys and sufferings. It obliges the artist not to keep himself apart; it subjects him to the most humble and the most universal truth (Camus, 2008b, pp. 239 - 240).

In the mid 1930's, still living in Algeria, Camus discovered and recognised the need for literary creation grounded in bearing witness:

From then on literature would not be a means of escaping from life: on the contrary, it would permit him to understand, to speak of, and to change life. Camus would never regard literature as diversion or an antithesis to reality but its witness (Lévi-Valensi, 2006, p. 148). 
With regards to his love life, he was married twice and had many romantic attachments, especially with the actress of Spanish descent María Casares. These relations tormented him deeply, the conflicting role of husband and lover, leading him to a complex state that he himself described in his final letter to the actress as a combination of passion and preoccupation (Todd, 1997, pp. 752 - 753). Despite his selfdeclared atheism, religious questions were never absent from his mind. He felt profound admiration for Christ and although he denied the resurrection, he was convinced of the mystery residing within the human being. Three years before his death he would describe his faith as "difficult" (Camus, 2008b, p. 242).

If it is normally difficult to separate an author's life from their work, in Camus' case this is virtually impossible given that his works contain his life in some way, enveloping it in each of its pages. His Carnets, his posthumously published diaries and his extensive correspondence, show that Camus believed that within a true artist authenticity, imagination and action must coexist to the point it becomes impossible to separate the creation from the life: "There is not one talent to live and another to create. The same talent serves both. And we can be sure that the talent that produces but one artificial work cannot but live a frivolous life" (Camus, 2008a, p. 1111).

Behind Camus' simple, fluid prose was hours of work and much rewriting. The original manuscripts are filled with corrections and annotations, as he was never entirely satisfied with the results. This desire for perfection, order, and structure would lead him to plan the entirety of his output from the very start of his career, winning him the Nobel Prize for Literature in 1957. This was a time when everyone, French intellectuals on both the left and the right isolated and repudiated him. How to resume Tanase, this particular attitude in a confrontation without nuances made Camus the enemy of all. Friends who shared his point of view, such as René Char or Jean Grenier, do not engage in the public debate, and the others break with him more or less openly (Tanase, 2018, p. 265).
This was evidenced even in the negative commentary in the press about his Nobel Prize speech. This rejection would last until his premature death in 1960 in an automobile accident, preserving until the end his ideological independence:

I had a precise plan when I began my work: I wanted, firstly, to express negation. In three forms: Novelistic: this was The Outsider. Dramatic: Caligula, The Misunderstanding. Ideological: The Myth of Sisyphus. I foresaw the positive also in three forms: Novelistic: The Plague Dramatic: State of Siege and The Just Assassins. Ideological: The Rebel. I glimpsed a third phase on the theme love (Grenier, 1987, p. 10).

It is surprising that someone may program their literary work from the very start of their profession; even more surprising is that they carry it out. Camus does so on different planes and using different styles. Without mixing genres and uniting the works of each phase as with an invisible thread, the author addresses the same themes using different optics to achieve a formal and existential unity of each phase and within his entire oeuvre. Thus, Camus' career can be divided into three different and structured phases, where each can be understood only through the others and so forming an indissoluble and progressive unity where, just as in life itself, there is progress and hope.

It is a vision of existence as something continuous, global. The first phase in Camus' work is the negative cycle or the absurd. The second is the positive cycle, revolt. The third, love, is the most imprecise, cut short by his death at the age of forty-six. Previously, in his formative years, nature imposed itself over all else. So, in June of 1947, shortly after the publication of La Peste, Camus outlines and expands his themes and works, identifying five series:

No tomorrow. $1^{\text {st }}$ series. Absurd. The Outsider. - The Myth of Sisyphus. - Caligula and The Misunderstanding. $2^{\text {nd }}$ series. Revolt: La Peste (and annexes). The Rebel. - The Just Assassins (Kaliayev). $3^{r d}$ series. The Trial; - The First Man. 
$4^{\text {th }}$ series. Tortured Love: The Bonfire. - On Love. - The Seducer.

$5^{\text {th }}$ series. Corrected Creations or The System - great novel + great meditation + unstageable piece (Camus, 2006a, pp.1084 - 1085).

Later, in 1950, Camus referenced his first three phases with three works associated with Greek mythology: "I. The Myth of Sisyphus (absurd). - II. The Myth of Prometheus (revolt). - III. The Myth of Nemesis" (Camus, 2008d, p.1093). It is interesting to consider that these phases were preceded by his early writings or first drafts.

Masson, speaking of a youthful period in almost pantheistic terms, structures it so: During childhood, the gods speak though nature, the sun, the sea, participating in the sacred to achieve harmony with the world, escape indifference and approach the absolute. Later, the indifference of the world distressingly imposes itself. Finally, the need to overcome the indifference of the world and reach the absolute is achieved only with the collaboration of others and with the support of a maternal figure (Masson, 2019, pp. 34, 41). The phases are characterised by their strong dialectic structure or the interplay of contraries, two sides of the same coin reinforced in a game of contrasts:

All of his work, philosophical essays, articles and fictional texts, turn on a firmly binary nexus of reality and the ideal, between the absurd and passion for life. Two antagonistic poles that "are the two faces of the same coin", anguish and joy, sun and shadow, tragedy and hope, sea and desert, exile and kingdom, setbacks and success, natal Algeria and mortal France (De Diego, 2006, p. 11).

Considering all of this, the present work will analyse one of the author's great novels, $L a$ Peste, part of the second phase and focused on the positive. We will primarily dedicate our analysis to the procedure used in the work to reach plenitude and progress; in this way, the work is a uniting social tool and the means for human beings to progress and improve, achieving true humanity and solidarity both as an individual and within a collective. Thus, the absurd is overcome. In the words of the author: "But also La Peste shows that the absurd teaches nothing. This is the definitive step" (Camus, 2006a, p. 955).

\section{Truth, Solidarity and Revolt in La Peste}

After five years of work, on June $10^{\text {th }}$, 1947, Albert Camus published La Peste, a realistic novel which narrates the history of the city of Oran in the grip of the plague and whose principal themes are death, solidarity, illness, and redemption. The real Oran in fact suffered an epidemic of cholera after French colonisation in 1849, and there is a rich interweaving of truth and fiction. The novel was a great success, selling many copies and admired by critics, interpreted as an allegory of the Nazi occupation and the desolation of Europe at the time. As we shall see, the novel goes further, its message is not fully understood at the time.

The plague that attacks the population can at times act as a cohesive element among people. As Camus himself writes in his diary entry of October 23rd, 1942: "La Peste has a social and metaphysical meaning. It is exactly the same. This ambiguity is also in The Outsider" (Camus 2006a, p. 965). Finally, two months later he would explore the idea further:

I want to express, by means of the plague, the suffocation we have all felt and the atmosphere of menace and confinement we have lived through. At the same time, I want to extend the interpretation to the notion of existence in general. The plague will portray those in the role of reflection, silence and also moral suffering in this war (Camus 2006a, p. 979).

The work is positive. It speaks of affirmation, of the affirmation of man to the world, born from the desire to give meaning to the "yes" of man to the bleak, hostile world that envelops everything. The book is part of the second series of books dedicated to the revolt of mankind. Following the classic model, the novel is structured into five parts preceded by an introduction, illustrating the progress of events in Oran and the various protagonists who, in a time of crisis, seek the restoration of 
the world and of themselves. In his early works, Camus combines a subjective discourse with an abandonment of theories in benefit of true submission to objective reality; the transformation of vision into contemplation, seeking harmony in reality (Lévi-Valensi, 2006, p. 97).

In the introduction, Camus beautifully almost poetically describes the city of Oran, a French prefecture on the coast of Algeria; a non-descript, ugly city without spirit or soul where life is bearable only in winter, while the intense, abrasive summer heat makes it almost uninhabitable. It is not difficult for the reader to imagine such as city, and it is testimony to the greatness of the author that he is able to evoke a certain sympathy and affinity for the city despite its limited charms. The beautiful words transform the insipid and bland into something compelling and attractive through a vividly direct, visual, and simple prose. As if by magic, the author transports us to a new world, invisible to us without him. And so literature serves to remake all things new, to give a different orientation to what already is. The literary is transmitted through images, multiplied tenfold in philosophy (Camus, 2006a, pp. 800, 936). For example:

Tree-less, glamour-less, soulless, the town of Oran ends by seeming restful and, after a while you go complacently to sleep there. It is only fair to add that Oran is grafted on to a unique landscape, in the centre of a bare plateau, ringed with luminous hills and above a perfect shaped bay. All we may regret is the town's being so disposed that it turns its back on the bay, with the result that it's impossible to see the sea, you always have to go look for it (Camus, 2006b, p. 37).

The narrative rests on the following four central characters: the doctor Bernard Rieux, the Parisian journalist Raymond Rambert, Father Paneloux, a Jesuit priest well-loved in the city even by the non-religious and Jean Tarroux a lover of writing and creator of the volunteer medical teams of which the four protagonists are members. These are solitary men who must overcome their individuality in order to join a collective, and thus complete themselves. In the novel, women are adored or remembered, present only as abstract thoughts.

Through shared doubts and pain, deaths, walks, readings, and bathing in the sea the protagonists exchange their beliefs and opinions, fundamental to the understanding of the other, their history, and heritage. Rieux is interested in human life, in this case, science serving in the fight against illness and pain. Concerned for his patients, he can be regarded as a good man and a good doctor, although he is unfortunately unable to prevent the death of his wife. As for Paneloux, as the novel progresses, he evolves from a rigid and dogmatic conception of religion to a more human vision. In his final sermon, he speaks of the plague as a personal challenge in which all without exception were implicated, and thus making essential the kind of religious belief we are offered but do not want, leaping to the heart of the unbearable in order to make our choice. Religion in the time of plague cannot be the religion of everyday, leaving no possibility other than to believe everything or deny everything (Camus, 2006b, pp. 189 - 190).

Tarroux tirelessly seeks peace through hope. Asking himself how one can become a saint without God (Camus, 2006b, p. 211). Holiness, as represented by Tarroux, is opposed to Christianity in that it implies life without hope. Fighting for life knowing the struggle is hopeless but having the courage to continue it as long as possible (Gadourek, 1963, p. 124). For this reason, Tarroux lives concerned and committed to human existence:

Tarroux thus concludes that "we all have plague", in that, one way or another we all (directly or indirectly) cause death, and what he seeks is the peace of mind that he has lost, which means having nothing to do with anything that can cause the death of another (Sherman, 2009, p. 126).

The fourth character is Rambert, who cannot bear the idea of remaining trapped in Oran, attempting to escape illegally to join his lover. Impatient to relive his own history, he will change his mind and attitude, deciding to join the fight against the plague and morally commit himself to the collective struggle and 
thereby, through his real contribution, restoring a chaotic and painful world.

The plague follows its natural cycle, developing in spring, virulent through the summer, subsiding in the autumn and dying with the cold of winter, something perceived, beyond the calendar, in the atmosphere and sky itself (Camus, 2006b, p. 35). Surviving the month of August will not be easy. At its height, the illness sweeps over the entire city:

(...) the plague had swallowed up everything and everyone. No longer were there individual destinies; only a collective destiny, made of plague and the emotions shared by all. Strongest of these emotions was the sense of exile and of deprivation, with all the crosscurrents of revolt and fear (Camus, 2006b, p. 149).

Only through solidarity, generosity and work can evil be fought, making it necessary to distinguish between heroism and love, the former very easy and, ultimately, criminal, while the latter requires honesty, and is never strong enough to find its true expression (Camus, 2006b, pp. 147, 235).

\section{Work as a Factor of Alienation or Liberation: Inclusion and Collective Progress}

The relation between work and La Peste is addressed by Albert Camus himself in a natural way. At the start of the narrative, the introduction, there are various allusions to the way the inhabitants of Oran earn a living, in a way which makes work and life inseparable:

Perhaps the easiest way of making a town's acquaintance is to ascertain how the people in it work, how they love, and how they die. In our little town, (is this, one wonders, an effect of the climate?) all three are done on much the same lines, with the same feverish yet casual air" (Camus, 2006b, p. 35).

Although in the first pages of the book work is described simply as a way to make money, something not exclusive to the people of Oran (Camus, 2006b, pp. 35-36). Gradually, we see a transformation in the habits and life of the city's inhabitants while still representing all of humanity. That all the various occupations have the same common purpose of earning money is something Camus himself associates directly with the modern world:

It will be said, no doubt, that these habits are not peculiar to our town; really all our contemporaries are much the same. Certainly nothing is commoner nowadays than to see people working from morn till night and then proceeding to fritter away at card-tables, in cafes and in small talk what time is left for living (Camus, 2006b, p. 36).

Evidently, people need time for recreation. The problem is that this time is often reduced to what can colloquially be referred to as "meantime". That is, in the meantime, when I am not working, not tied or not occupied with other things, I have time to relax, dedicate time to others and so survive until the time comes. Far from this notion of "meantime", work is conceived here as the manner in which human beings live, with work being an essential part of life, along with all the other tasks and plans, many of these being work themselves, although of different forms or type.

Individual existence has no meaning unless associated with others, expressed in the novel in the collaboration between citizens and the help the characters give to each other. Humanity includes us all. Work is how we show who we are and wish to be: "Rieux remarked that one couldn't always be alone" (Camus, 2006b, p. 73). The young Camus was initiated into the specific reality of work through his uncle Étienne, a cooper, and with this model he assimilated the idea of the worker as an artisan producing an object. His unfinished novel, The First Man, gives testimony to this initiation and the mark it left on him through the character of Jacques Cormery:

For him, an example of real work was cooperage, a lengthy physical effort, a series of skilful, precise actions, by strong and able hands and you saw the result of your labour take shape: a new barrel, well finished, without a flaw, that the worker could contemplate (Le Marinel, 2009, pp. 899 900). 
The verb to do is not necessarily a synonym for work, actions without thought or purpose are not proper to human beings, destined for balanced and measured development. According to Aristotle, the deployment of our faculties permits us to progress and improve, engaging in our lives as a project that is created and developed: The prudent man is able to deliberate well about what is good and advantageous for himself, not in some one department, but what is a means to the good life in general (Aristotle, 1998, p. 275). Even in Aristotle's time, work was the basis of social and moral existence, there being no other way to mature or progress socially, although this notion was not primarily focussed on the specific individual as in our day.

Here, there is an essential difference between nature and human beings. Nature is neutral. Human beings can never be so. Through our acts and our work, we define ourselves; work being a part of the personal labour we perform during the course of our lives. We dedicate many hours to work, and for some perhaps more than we should, which is certainly true when work leads to personal isolation and estrangement from family and friends. Work is not slavery but selfgovernment. As another members of the team fighting the plague remarks:

The rest of the story, to Grand's thinking, was very simple. The common lot of married couples. You get married, you go on loving a bit longer, you work. And you work so hard that it makes you forget to love (Camus, 2006b, p. 89).

That we are not neutral means that we have freedom; that we can live according to who we are and what we want. Thus, nature ceases to be neutral the moment human beings give it meaning. In work, we experience a triple engagement with meaning, with others, with nature, with transcendence. Work is a cohesive element or a restorer of balance, playing the same role in our lives as the plague in Oran, unifying the person by giving balance. For Camus there is a perpetual interplay of forces between man and the world, seeking the proper balance. And the measure of this balance is justice (Mattéi, 2011, p. 134). Just as nature ceases to be anodyne when we engage with it, others cease to be strangers, becoming our fellows in our endeavours and giving meaning to human nature as the measure or limit of all things:

If the notion of this anti-life is associated with violence and domination, Camus gives a response that, far from the existentialism often attributed to him, rests on the concept of human nature as the limit for will and praxis (Montero, 2016, p. 193).

It is common for us to face various impediments to our work that hinder us from achieving our purposes and goals, which in turn often orient human occupations and thus frustrate our will:

Lastly, Tarrou seemed to have been quite fascinated by the commercial character of the town, whose aspect, activities, and even pleasures all seemed to be dictated by considerations of business (Camus, 2006b, p. 51).

We often blame time for the gulf between our duty, our wishes, and our actions; something which also appears in the novel: "At Oran, as elsewhere, for lack of time and thinking, people have to love one another without knowing much about it" (Camus, 2006b, p. 36). The city and the surroundings influence the life of the citizens, alienating or liberating people from their burdens and oppressions. The goal is to do the same, working equally with but options, alienation or liberation, what changes is the attitude of the subject before the chosen option, the intimate: "But, actually, it was a problem whether the change was in the atmosphere or in their hearts" (Camus, 2006b, p. 102). Alienation excludes any possibility, avenue or route of escape while liberation necessarily invites us to accept without resignation the influencing but by no means determinant context. Alienation makes us prisoners of work, of the plague. Liberation will not permanently defeat the epidemic, but it will allow us to face it, aspiring to a hopeful outcome. Alienation invites us to surrender, to go along, while liberation fires our awareness. 
We defend the notion of work as vocation, as union with oneself, with others and with nature, as opposed to the Marxist idea of work as alienation. Work engages us with the world, reconciles us to others and with our own self. We know and recognise ourselves through our engagement with others: "To know yourself you must act, which does not mean one can define oneself" (Camus, 2006a, p. 834). Through our profession we discover an unsatisfactory world around us, a world downtrodden by evil and misfortune we wish to fight against. It is precisely in action, in the forceful attitude of collaboration, that we discover our true role. Work dignifies, beginning anew again and again: "- No, you haven't understood that it means exactly that the same thing over and over and over again" (Camus, 2006b, p. 146).

Camus himself, in producing his literary creations, sides decisively with others, forgetting himself and focussing on his work in pursuit of the ideal of beauty, the absolute where form and substance become inseparable. Literature is his life, just as medicine is life for Rieux, which can only be understood as a unity and not small isolated fields of activity. It is this false dichotomy that, now more than ever our hyper-specialised world, is presented as an infallible method for success. The notion that life is work and work is life does not mean to limit existence to one's professional occupations. We do much work, in many forms, even when retired or ill we continue to work. Personal coherence lies in combining the affective and the rational within the free individual: "I propose to invert the classic formula and that work becomes the fruit of recreation. There is dignity in the small chores we do on Sundays" (Camus, 2006a, p. 854). In the novel, doctor Rieux assumes the duty to protect, to remain with his patients, and to help them on their way. As the character himself states, his mission in life is nothing more than to give opportunities (Camus, 2006 b, p. 138). First the doctor and then the others put a name to the evil that Oran: "It was only a matter of lucidly recognising what had to be recognised; of dispelling extraneous shadows and doing what needed to be done" (Camus, 2006b, p. 61). By naming things we accept their existence, we take them on board. This is the point of departure. The manifest fact of the plague makes everyone equal leading the doctor to compassion through absolute liberty:

Truth is mysterious, always to be conquered. Liberty is dangerous, as hard to live with as it is elating. We must march toward these two goals, painfully but resolutely, certain in advance of our failings on so long a road (Camus, 2008b, p. 242).

From the "absurd" to "revolt" to the "first man", Camus never ceases to place at the very centre of his work the fundamental question of man, his problematic position in an absurd world and to defend his conception of human dignity (Corbic, 2007, p. 12). Concern about human beings, Camus denounces injustice and the artistic inseparability of beauty and community, but not limited to art: "The artist forges a perpetual coming and going from himself to others, midway between the beauty he cannot do without and the community he cannot tear himself away from" (Camus, $2008 \mathrm{~b}$, p. 240 ). The plague that grips the city assumes the role of the absurd, the first phase of Camus' work; it is in the second phase that the battle is won. The new plague of Israel that leads to human liberation. The plague circumscribes existence; it is oppression, exile, the German domination of Europe. It remains hidden and silent, prowling, defeating it one time does not mean final victory. As with evil, it is a tireless foe, waiting patiently to be freely chosen again. There are many plagues which surround us and many rats we can become. As Camus states at the end of the novel:

(...) for the plague bacillus neither dies nor disappears. It can lie dormant for years and years, in furniture and in linen chests. Biding its time in bedrooms, in cellars, in trunks, in handkerchiefs, and in the odd scrap of paper. And the day will come when, to the bane and enlightenment of man, the plague will awaken its rats and send them forth to die in the happy city (Camus, 2006b, p. 248).

\section{Conclusion}

For Camus, creation consists in reliving in some way the lived, ennobling it. The result of this process is called art. Many writers, 
philosophers and poets have written and worked around the ideal of truth, beauty and good. The endeavour of the artist is a work of arduous and profound craftsmanship that will only conclude with the end of the world. The novelty of art is not in the material used nor the message proclaimed but in the form of the telling, the mystery. The novelty of art resides in the specific order of an author's words, the notes on a musical score or the shape chiselled by a sculptor. The artist knows that the result of the creative process belongs to humanity, although it once belonged to them.

We are all co-creators on two essential levels: our existence and our work. But we must be so in a single sense, in a life that includes work and the world, permeating the human self and human endeavour. Today more than ever we are prisoners of a multiform reality, expending huge amounts of energy, money and time in magical solutions that promise to resolve our post-modern schizophrenia.

These unfortunately only serve to worsen the situation. True hope lies in the unity of the self, in personhood and its multiple occupations, the unity of the world in contemplative love and compassion. All work is called upon to be a work of art; a work that does not belong to us, but both contains and commands us.

Camus died leaving unfinished what would be his last novel The First Man. The 142page manuscript was found in a suitcase he had with him on the day of the fatal accident. With his death went the rebel, the artist who would not bend to the general views of his time nor submit to the political or cultural majorities of the moment. Today, some sixty years after his premature departure, we continue to find his work fresh and timely, stamped with his strong personality and creative sensibility.

Camus was always profoundly concerned with communicating, with writing about questions that bore on human beings, their essence and their rights. His message continues to be as necessary now as when Europe was torn by war. Today we fight in other wars, with other means and worries, but the interior emptiness remains the same; we need to find the answer to the same questions and anxiously search for meaning. The work of Albert Camus remains a beacon in the darkness, a starting point of revolt and encounter with the intimate, personal and inalienable self.

\section{References}

Aristotle. (1998). Ética Nicomáquea, Madrid: Gredos.

Camus, A. (2006a). Carnets 1935 - 1948, en: Camus, A., Oeuvres Complètes. II. 1944 1948, pp. 793 - 1125. París: Gallimard.

Camus, A. (2006b). La Peste, en: Camus, A., Oeuvres Complètes. II. 1944 - 1948, pp. 31 - 248. París: Gallimard.

Camus, A. (2008a). Carnets 1949-1959, en: Camus, A., Oeuvres Complètes. IV. 1957 1959, pp. 997 - 1307. París: Gallimard.

Camus, A. (2008b). Discours de Suède, en: Camus, A., Oeuvres Complètes. IV. 1957 1959, pp. 235-266. París: Gallimard.

Corbic, A. (2007). Camus et l'homme sans Dieu, París: Les éditions du Cerf.

De Diego, R. (2006). Albert Camus, Madrid: Síntesis.

Gadourek, C. (1963). Les Innocents et les Coupables. Essai d'exégèse de l'oeuvre d' Albert Camus, Mouton: The Hague.

Le Marinel, J. (2009). “Travail” en: Guérin, J. (Dir.), Dictionnaire Albert Camus, pp. 899 901. París: Éditions Robert Laffont.

Lévi-Valensi, J. (2006). Albert Camus ou la naissance d'un romancier, París: Gallimard.

Babe Grenier, R. (1987). Albert Camus. Soleil et Ombre. París: Gallimard. 
Mattéi, J.-F. (2011). "L' Étranger entre refus et consentement" en: Mattéi, J. F. (Coord.), Albert Camus. Du refus au consentement, pp. 127 - 159. París: PIF.

Masson, P. (2019). "Le sacre du silence" en: Auroy, C. y Proteau, A. (Edit.), Albert

Camus et les vertiges du sacré, pp. 31 - 41. Rennes: Presses Universitaires de Rennes

Montero, D. (2016). "Enfermedad y caída en Albert Camus", Logos. Anales del seminario de metafísica, Vol. 49, pp. 189 - 209. Madrid: Ediciones Complutense,

Sherman, D. (2009). Camus. Oxford: WileyBlackwell.

Tanase, V. (2018). Camus. Traducción de: Ana García, Barcelona: Plataforma editorial.

Todd, O. (1997). Albert Camus. Una vida. Traducción de: Mauro Armiño, Madrid: Tusquets Editores. 